\title{
Key Predictors of Employee Commitment and Organizational Citizenship Behavior
}

\author{
E. Veronica ${ }^{1} \&$ R. Indradevi ${ }^{1}$ \\ ${ }^{1}$ VIT Business School, VIT University, Vellore, Tamilnadu, India \\ Correspondence: R. Indradevi, VIT Business School, VIT University, Vellore, Tamilnadu, India. E-mail: \\ rindradevi@vit.ac.in; indrabalu@hotmail.com
}

Received: February 19, 2014 Accepted: May 4, 2014 Online Published: June 25, 2014

doi:10.5539/ass.v10n13p22

URL: http://dx.doi.org/10.5539/ass.v10n13p22

\begin{abstract}
Employee Commitment is the bondage an employee possesses towards his organization. Building Employee Commitment (EC) to the work place is the need of the hour for all the organizations. Nowadays no organization can execute at high level unless otherwise employees are committed to the organizations goals. Commitment could be described as the Holy Grail of organizational performance and business psychology. Hence, it is significant to recognize the concept of commitment and its feasible outcomes. Organizational Citizenship Behavior (OCB) is assumed as one of the rising management perception of managerial efficacy.

This study intends to focus on key predictors of employee commitment and organizational citizenship behavior. A quantitative research is employed to explore the predictors of EC and OCB. The study identified six factors that predicted employee commitment and five factors that predicted organizational citizenship behavior.
\end{abstract}

Keywords: employee commitment and organizational citizenship behavior

\section{Introduction}

\subsection{Employee Commitment}

Commitment is an emotional situation that combines an individual to the organization. It refers to the probability that an individual attach himself to the organization and felt psychologically involved to it, whether the job is rewarding or not. Commitment is the stage of relationship that employees feel towards their organization. They feel that they are bonded with the organization and are intense to carry on working for it. Committed employees add value to the organization because they are strong minded, give realistic support, produce more and pay concentration to quality. As well as, they do not report ill so often and are less possible to depart the organization. Employees without commitment can work beside the organization and hold back its success.

(Allen \& Meyer, 1990) have projected a three-component model to illustrate employee's commitment towards organization. They said that employee's commitment get initiated for three reasons, such as (a) emotional attachment (b) feeling of obligation and/or (c) economic reason. They named these as three components of commitment as- affective commitment, normative commitment and continuance commitment.

\subsection{Affective Commitment}

Affective commitment is employee's affection with the organization and its purposes. This add-on may develop due to various factors such as brand image of the organization, independence, demanding tasks, relationship with colleagues, superiors and subordinates and other work circumstances.

\subsection{Normative Commitment}

An employee feeling of relationship to stay with the organization is described as normative commitment. This sense of obligation may develop owing to some positive activity that the employees value and treasure in the organization. For instance, nominating an employee to a training program that helps him in his career advancement is likely to create a sense of obligation. Similarly, extending support to employees beyond the normal policies of the organization at the time of some emergency/unforeseen circumstances creates a sense of obligation. 


\subsection{Continuance Commitment}

Continuous commitment is where an employee prefers to stay in the organization mainly to satisfy his needs. He has no options available and no other sources of job alternative or losing this job can be a high cost for him.

(Meyer \& Allen, 1991) described about commitment as true fact to illustrate the employee's relationship in the organization and that state the insinuation for decisions to carry on or to stop attachment in the organization. Affective, continuance, and normative commitment are not commonly restricted. An affective and normative commitment is highly linked whereas there is a negative association between the affective and continuance commitment. (Mayer, Allen, \& Smith, 1993).

\section{Literature Review}

\subsection{Determinants of Employee Commitment}

There are several factors that can positively or negatively influence the commitment of employees. Generally employees find it very tough to fit in the organization and they don't have a clear idea how to contribute to the organization as a whole. Whereas in employee survey a clear vision is identified whether employees are committed or not and whether the employees intend to leave the organization. Employees who are not committed seek for other jobs. But dedicated employees are also looking in the region of other jobs. In this case, an organization needs to do something to withhold their employees. It is imperative for an organization to give clearness to its individuality and vision to make it clear.

\subsubsection{Drivers of Employee Commitment}

(Bragg, 2002) identified various drivers of employee's commitment. They are:

- Fairness: It implies the removal of one's feelings, bigotry and desire to attain an appropriate equilibrium between contradictory and wellbeing.

- Trust: Committed employees shall be faithful to their organization.

- Concern for employees: Employees should be looked upon as people and as assets of the organization and not as factors of production.

\subsubsection{Strategies for Increasing Employee Commitment}

There are several ways to improve employee commitment. Whereas employers frequently fail to understand some useful things that they can extend and maintain to encourage the dedicated employees. (Nelson, 1999)

- Interesting work: No one wants to do the similar tedious job again and again and day after day. Furthermore, any job always requires some uninteresting, repetitive tasks that every employee is supposed to do. Everyone should have high awareness of their job; they should also understand the importance of their job and their role in it, which would make their job more interesting.

- Information: Information is fact and employees should be empowered with the information that they need to do their works which will enhance their efficiency. Since most of the employees want to know their job description and organizational performance, open channels of communication in an organization will permit the employees to be informed, ask questions and split the information.

- Involvement. Employees are involved in the decision making of the organization. They are given the opportunity to participate in all decision making and problem solving situations and give their valuable opinions.

- Independence: Some employees desire their every deed to be clearly monitored. But most of the employees are grateful for having the flexibility to do their work with independence. Generally if people are given freedom to increase the chance to carry out their desires, then they would bring extra proposal, ideas and energy to their jobs.

- Increased visibility. Everyone shall be grateful for receiving credit when it is unpaid. Occasions to split the achievement of employees with others are roughly boundless. Giving employees with new opportunity to execute study and produce as a form of credit and gratitude is highly inspiring for majority of the people.

(Madigan, Norton, \& Testa, 1999) afforded the realistic strategies that organizations can use to raise employee commitment. They recommended that, for an organization to boost the commitment levels of its employees and to satisfy their primary needs, they need to uphold their work-life balance.

Thus commitment acts as a person's strong positive reaction towards the organization and its goals. There is an individual recognition and feelings of pride in the organizations accomplishment. An individual append is based on his or her wish to take benefit of what the organization has to provide in terms of need- satisfying rewards. 


\subsection{Organizational Citizenship Behavior}

It was 1983 when Bateman and Organ introduced the term "citizenship" as behaviors that smear to share the equipments of the organization and it tagged the employees to hold such behaviors as "good citizens". Although the history of OCB is not very old, its roots can be drawn back. (Barnard, 1938) Employees who are keen to achieve organizational goals should be willing to add hard work to the supportive system.(Katz, 1964) and (Katz \& Kahn, 1966) focused that productive and cooperative behaviors are away from conventional job requirements and it plays an vital role for the successful performance of an organization.

Organizational citizenship behaviors comes in a range of forms such as loyalty, helping others, organizational compliance (Podsakoff, MacKenzie, Paine \& Bacharach, 2000) and organizations benefits of the employees who are ready to supply their hard work and skills to the organizations even though that is not formally required by them. This involvement of organizational citizenship behavior to organizations has already established much thought in the business Arena.

Organizational Citizenship Behavior (OCB) is an exclusive feature of individual actions at work. (Organ's, 1988), defined Organizational Citizenship Behavior as "individual behavior that is flexible are not directly or explicitly accepted by the proper reward system and the mutual sustain acts as a efficient and effective performance of the organization".

Organizational citizenship behavior (OCB) is passing on a flexible work place action that goes beyond one's basic job requirements. They frequently express the behavior that exceeds the call of task. OCB is wide since its beginning almost twenty years back (Bateman \& Organ, 1983). The huge number of OCB research has focused on the effects of OCB on individual and managerial act. There is consent in this exacting field that OCB tackle quiet behaviors for organizational activity. (Barbuto, Brown, Wilhite \& Wheeler, 2001).

(Organ, 1988) argued that OCB is detained to be essential for the existence of an organization. Organ later intricate that organizational citizenship behavior can make the most competence and efficiency of both the employee and the organization that eventually supply the effective execution of an organization. Well-known present organizational researchers have consented with Organ's view on organizational citizenship behavior. (George \& Brief, 1992).

The two key components of OCB are compliance, which point out the employees purpose to go behind the organizational rules and humanity, which means employees intended behaviors help others and to work. (Organ \& Ryan, 1995; Williams \& Anderson, 1991)

\section{Research Objectives}

> To discover the factors that influence employee commitment in manufacturing companies.

$>$ To identify the factors that predicted organizational citizenship behavior in manufacturing companies.

\section{Methodology}

The questionnaire used in the present study is adopted from the research studies of (Allen and Meyer 1990), (Bragg, 2002), (Randall, 1987), (Nelson, 1999), (Madigan, Norton, \& Testa, 1999), (Organ, 1983), (Barnard, 1938), (Katz, 1964), (Podsakoff, MacKenzie, Paine, \& Bachrach, 2000). The questionnaire consisted of 29 items for employee commitment and 24 items for organizational citizenship behavior with closed ended questions on a five point Likert scale ranging from 5 - strongly agree to 1 - strongly disagree.

The responses were collected from the employees of manufacturing Industry. A convenient sampling technique was used for the survey. A total of 53 items was used for this survey excluding demographic characteristics. The statistical package for social science (spss, version 20) was used to analyze the data. The reliability test has been conducted to verify the internal consistency of the variables obtained in the sample. The cronbach's alpha is found to 0.918 , which is much higher than the minimum acceptable level suggested by (Nunally, 1978). Factor analysis was used to analyze the data.

\section{Data Analysis}

The researchers conducted reliability test for all 29 items on employee commitment and the cronbach's alpha is found to 0.864 which is presented in table 1

Table 1. Reliability Test

\begin{tabular}{cc}
\multicolumn{2}{c}{ Reliability Statistics } \\
\hline Cronbach's Alpha & No of Items \\
.864 & 29 \\
\hline
\end{tabular}


Being satisfied with the reliability of the instrument, the researcher carried out the factor analyses to find out the factors influencing employee commitment and organization citizenship behavior.

\subsection{Factors for Employee Commitment}

After deciding on the 29 items for Employee commitment factor analysis was carried out to identify the underlying factor of Organizational citizenship behavior. But before proceeding on with factor analysis, few preliminary tests like Kaiser Meyer-Olkin measure of sampling Adequacy (.741) was done to justify that factor analysis is an appropriate tool for the present study. (Kaiser, 1974) recommends accepting values greater than 0.5 as acceptable.

Table 2. KMO and Bartlett's test

\begin{tabular}{llr}
\hline Kaiser-Meyer-Olkin Measure of Sampling Adequacy. & .741 \\
& Approx. Chi-Square & 1051.143 \\
Bartlett's Test of Sphericity & Df & 406 \\
& Sig. & .000 \\
\hline
\end{tabular}

KMO and Barlett's test of sampling adequacy is 0.741 for employee commitment. There are two stages in factor analysis. Stage one being the factor extraction process, wherein the objective of the study is to identify how many factors are extracted from the data. The result of the factor analysis is provided in table 3 . Six factors on employee commitment was extracted which accounted for $40.164 \%$ of the cumulative variance.

Table 3. Factors for employee commitment

\begin{tabular}{lccc}
\multicolumn{1}{c}{ Variables } & $\begin{array}{c}\text { Factor } \\
\text { Loading }\end{array}$ & $\begin{array}{c}\text { Factor } \\
\text { Alpha }\end{array}$ & $\begin{array}{c}\text { Factor } \\
\text { Mean }\end{array}$ \\
\hline Factor 1: Career Advancement & & $\mathbf{. 7 4 4}$ & $\mathbf{3 . 5 7 9}$ \\
I feel that I am happy in my work in this organization & .737 & &
\end{tabular}

I am satisfied with the chance to do something that

makes use of abilities

I can predict my future career path in this

organization by observing other people experience

I feel I would lose valuable relationships with the

people hereby quitting this organization

Factor 2: Job Realization

My experiences as a manager in the organization

have fallen short of my expectation

I feel that I cannot depend on this organization to

fulfill its obligations to managers at my level

I feel that this organization is dependable

I feel that senior management in this organization try

to get of their obligation to lower level managers

Factor 3: Achievement 
I am happy with the feeling of accomplishment I get

from doing my job

Organization has in place an effective program for

internally developing its managers

I understand how my particular work group

contributes to this organization goals

Factor 4: Autonomy

I am satisfied with the freedom to use my own

judgment

My job is very enjoyable

My job is like a hobby to me

\section{Factor 5: Supportiveness}

My colleagues have gone out of their way to help me to adjust to this organization

I am not satisfied with the benefits Ii have

I can trust my colleagues to lend me hand when I need it

\section{Factors 6: Job enhancement}

I have all the skills I need to do my job

I understand this organizations goals and objectives

I find real enjoyment in my work
.825

.532

\section{Factor 1}

Four items like Work Happiness, Job Advancement, Future career path and Losing Relationship were loaded under factor one with loading range from .73 to .54 . The alpha value for the first factor is .744 and the mean value is 3.579 which indicate that there is a strong level of agreement among the respondents for factor one. The items loaded under factor one emphasize the importance of career. Hence the factor one is named as Career Advancement factor.

\section{Factor 2}

Four items like Fallen Short Expectation, Not dependable, Dependable Organization and Obligation to lower level were loaded under factor two with loading range from .72 to .56. The alpha value is .674 and the mean value is 3.424 which indicate that there is a strong level of agreement among the respondents for factor two. The items loaded under factor two emphasize the importance of job. Hence the factor two is named as Job Realize factor.

\section{Factor 3}

Three items like Accomplishment, Internal develop and Contribution of Work were loaded under Factor three with loading range from .82 to .57 . The alpha value for the third factor is .698 and the mean value is 3.611 which indicate that there is a strong level of agreement among the respondents for factor three. The items loaded under factor three emphasize the importance of accomplishment. Hence the factor third is named as Achievement factor. 


\section{Factor 4}

Three items like Employees Own Judgment, Job Enjoyable and Jobs Hobby were loaded under Factor four with loading range from .74 to .65. The alpha value for the fourth factor is .642 and the mean value is 3.636 which indicate that there is a strong level of agreement among the respondents for factor four. The items loaded under factor four emphasize the importance of independence. Hence the factor fourth is named as Autonomy factor.

\section{Factor 5}

Three items like Colleagues Help, Received benefits and Trust My colleagues were loaded under Factor five with loading range from .77 to .59 . The alpha value for the fifth factor is .623 and the mean value is 3.432 which indicate that there is a strong level of agreement among the respondents for factor five. The items loaded under factor five emphasize the importance of adjustment. Hence the factor fifth is named as supportiveness factor.

\section{Factor 6}

Three items like Skills Required, Organizations goals and objectives and Work Enjoyment were loaded under Factor six with loading range from .82 to .53. The alpha value for the sixth factor is .575 and the mean value is 3.954 which indicate that there is a strong level of agreement among the respondents for factor six. The items loaded under factor six emphasize the importance of development. Hence the factor sixth is named as Job Enhancement factor.

\subsection{Factors for Organizational Citizenship Behavior}

The reliability test was conducted for all 24 items on organization citizenship behavior and the cronbach's alpha is found to 0.835 which is presented in table 4

Table 4. Reliability test

\begin{tabular}{cc}
\hline \multicolumn{2}{c}{ Reliability Statistics } \\
\hline Cronbach's Alpha & No of Items \\
.835 & 24 \\
\hline
\end{tabular}

After deciding on the 24 items for organizational citizenship behavior, factor analysis was carried out to identify the underlying factors.

KMO and Barlett's test of sampling adequacy is 0.775 for organizational citizenship behavior which is presented in table 5 .

Table 5. KMO and Bartlett's test

\begin{tabular}{llr}
\hline Kaiser-Meyer-Olkin Measure of Sampling Adequacy. & .775 \\
Bartlett's Test of Sphericity & Approx. Chi-Square & 675.380 \\
& Df & 253 \\
& Sig. & .000 \\
\hline
\end{tabular}

From 24 items only 17 items got loaded into 5 factors in organizational citizenship behavior which together accounted for $57.113 \%$ of cumulative variance. . The result of the factor analysis is provided in Table 6 .

\section{Factor 1}

Five items like Complaining about trivial matters, Behavior affects, Squeaky wheels, Abreast of changes and Action on co-workers were loaded under factor one for organizational citizenship behavior with loading ranging from .71 to .54 . The alpha value for first factor is .764 and the mean value is 3.483 which indicate that there is a strong level of agreement among the respondents for factor one. The items loaded under factor one emphasize the need for having the changes and action on co-workers. Hence the factor one is named as Humanity.

\section{Factor 2}

Five items like Help others problem, Conscientious employees, Extra breaks, Helping hand around me and Orientation were loaded under factor two with loading ranging from .66 to .51. The alpha value for factor two 
is .666 and the mean value is 3.689 which indicate that there is a strong level of agreement among the respondents for factor two. The items loaded under factor two emphasize the need for having the Conscientious employees. Hence factor two is named as diligence.

Table 6. Factors for organization citizenship behavior

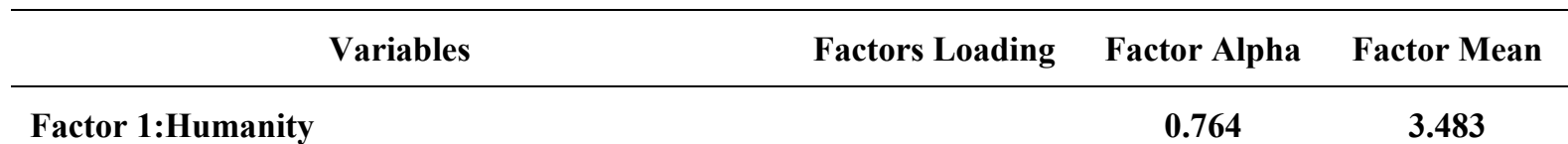

I consume a lot of time complaining about trivial matters

I am mindful of how my behaviors affects other

people jobs

I am the classic "squeaky wheel" that always needs greasing

I keep abreast of Changes in the organization

I consider the impact of my action on coworkers

\section{Factor 2: Diligence}

0.666

3.689

I willingly help others who have work related

problems

I am one of the most conscientious employees

I do not take extra breaks

I am always ready to lend a helping hand to those around me

I help orient new people even though it is not required

\section{Factor 3: Sportsmanship}

I believe in giving an honest days works for an honest pay

I try to avoid creating problem for co-workers

I obey company rules and regulation when one is watching

\section{Factor 4: Courteousness}

0.636

I always find fault with what the organization doing

I always focuses on what's wrong rather than the positive side

\section{Factor 5: Deliberation}




\section{Factor 3}

Three items like honest day works, Creating problems and Company rules were loaded under factor three with loading ranging from .72 to .58. The alpha value for factor three is .599 and the mean value is 3.849 which indicate that there is a strong level of agreement among the respondents for factor three. The items loaded under factor three emphasize the need for avoiding complains. Hence the factor three is named as Sportsmanship.

\section{Factor 4}

Two items like Find fault and Negative thought were loaded under factor four with loading ranging from .82 to .71. The alpha value for factor four is .636 and the mean value is 3.546 which indicate that there is a strong level of agreement among the respondents for factor four. The items loaded under factor four emphasize the need for having the negative thought. Hence the factor four is named as Courteousness.

\section{Factor 5}

Two items like Help absentees and Prevent problems were loaded under factor five with loading ranging from .82 to .50 . The alpha value is .529 and the mean value is 3.870 which indicate that there is a strong level of agreement among the respondents for factor five. The items loaded under factor five emphasize the importance for helping the employees. Hence the factor five is named as Deliberation.

\section{Conclusion}

This study identified the factors for Employee commitment and Organizational citizenship behavior. Employees committed to their career may endeavor to be terrific expert in their work and share its goals and values. This study has identified strategies like career advancement, job realization, employee achievement, autonomy given to employees, supportiveness of the management to their employees and enhancing the job of the employees as important predictors that enhances the commitment of the employees towards their organization.

Organizational citizenship behaviors enhance organizational effectiveness in several ways. The factors that enhance the citizenship behavior of the employees are humanity, diligence, sportsmanship, Courteousness and deliberation.

Hence it becomes necessary for organizations to focus on the above mentioned factors to enhance their employee's commitment and citizenship behavior. These two are the vital force and key of success for any organizations.

\section{References}

Allen, N. J., \& Meyer, J. P. (1990). The measurement and antecedents of affective, continuance and normative commitment to the organization. Journal of Occupational Psychology, 63, 1-18. http://dx.doi.org/10.1111/ j.2044-8325.1990.tb00506.x

Barbuto, J., Brown, L., Wilhite, M., \& Wheeter, D. (2001). Justify the underlying motives of organizational citizenship behavior: A brief study of agricultural co-op workers.

Barnard, C. I. (1938). The functions of the executive. Cambridge, MA: Harvard University Press.

Bateman, T. S., \& Organ. (1983). Job satisfaction and the good soldier: The relationship between affect and employee citizenship. Academy of Management Journal, 26, 587-595. http://dx.doi.org/10.2307/255908

Bragg. (2002). Improve Employee Commitment. Industrial Management, 18-19.

George, J. M., \& Brief, A. P. (1992). Feeling good-doing good: A conceptual analysis of the mood at work-organizational spontaneity relationship. Psychological Bulletin, 112, 310-329. http://dx.doi.org/ 10.1037/0033-2909.112.2.310

Kaiser, H. F. (1974). An index of factorial simplicity. Psychometrika, 39, 31-36. http://dx.doi.org/ 10.1007/BF02291575

Katz, \& Kahn. (1966). The social psychology of organizations. New York: Wiley.

Katz, D. (1964). Motivational basis of organizational behavior. Behavioral Science, 9, 131-146. http://dx.doi.org/ $10.1002 /$ bs.3830090206

Kohan, A., \& Mazmanian, D. (2003). Police work, burnout, and pro-organizational behavior: A consideration of daily work experiences. Criminal Justice and Behavior, 30, 559-583. http://dx.doi.org/10.1177/0093854803254432

Madigan, M., Norton, J., \& Testa, I. (1999). The Quest for Work ñ Life Balance [online]. Rogers Media. 
Meyer, J. P., \& Allen, N. J. (1991). A three-component conceptualization of organizational commitment. Human Resource Management Review, 1(1), 61-89. http://dx.doi.org/10.1016/1053-4822(91)90011-Z

Meyer, J. P., \& Allen, N. J. (1993). Commitment to organizations and occupations Extension and test of three-component conceptualization. Journal of Applied Psychology, 78, 538-551. http://dx.doi.org/10.1037/ 0021-9010.78.4.538

Nelson, B. (1999). Low cost ways to build employee commitment. Nelson Motivation Inc. Retrieved from http://www.inc.com/articles/1999/12/16412.html

Nunnally, J. C. (1978). Psychometric theory (2nd ed.). New York: McGraw-Hill

Organ, D. W. (1988). Organizational citizenship behavior: The good soldier syndrome. Lexington, MA: Lexing-ton Books.

Organ, D., \& Ryan, K. (1995). A meta-analytic review of attitudinal and dispositional predictors of organizational citizenship behavior. Personnel Psychology, 48, 775-802. http://dx.doi.org/10.1111/j.17446570.1995.tb01781.x

Podsakoff, P. M., Mckenzie, S. B., Paine, J. B., \& Bacharach, D. (2000). Organizational citizen ship behaviors: A critical review of the theoretical and empirical literature and suggestions for future research. Journal of Management, 26(3), 513-563. http://dx.doi.org/10.1177/014920630002600307

Randall, D. M. (1987). Commitment and the organization: The organization man revisited. Academy of Management Review, 12, 460-471

Williams, L., \& Anderson, S. (1991). Job satisfaction and organizational commitment as predictors of organizational citizen-ship and in-role behaviors. Journal of Management, 17, 601-617. http://dx.doi.org/ $10.1177 / 014920639101700305$

\section{Copyrights}

Copyright for this article is retained by the author(s), with first publication rights granted to the journal.

This is an open-access article distributed under the terms and conditions of the Creative Commons Attribution license (http://creativecommons.org/licenses/by/3.0/). 